原著

外科臨床に括けるエンドトキシン血症の発来について

一とくに急性汎発性腹膜炎を中心として一

日本医科大学第 1 外科（指導：主任教授 代田明郎）

助手 滝 沢 隆 雄

\title{
THE CAUSES AND MECHANISMS OF ENDOTOXEMIA IN THE SURGICALLY \\ TREATED PATIENTS, WITH SPECIAL REFERENCE \\ TO ACUTE PERITONITIS
}

Takao TAKIZAWA

First Department of Surgery, Nippon Medical School

(Director : Prof. Akiro SHIROTA)

著者は細菌感染を有するか，あるいはまたその病態に細菌が一つの重要な役割を果し ていると思われる外科的消化器疾患におけるェンドトキシン血症の発現頻度を Limulus

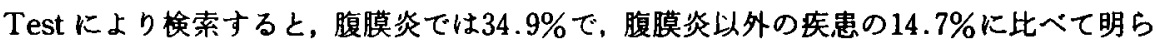

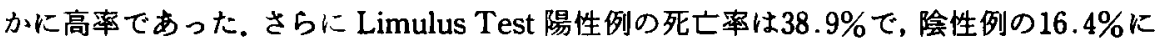
比べて明らかに高い值を示し，とくに腹膜炎では陽性例が50\%で，陰性例の $21.9 \%$ に比 ベて著しく高い値を示した。

そこで，腹膜炎の死因におよぼす腸内細菌，とくにグラム陰性桿菌のエンドトキシン についての役割を明らかにするために，主として無菌動物を用いて実験的に研究した。

ICR 系無菌マウスに腸管穿孔を起こすと，腹膜炎が惹起され，無菌群の生存時間は平 均164時間であったのに対し,大腸菌単独污染群の生存時間は無菌マウス群に比べて約1/ 6とい5短緶がみられた。無菌群の腹腔内と腸管内容は全く無菌であったが, 大腸菌単独 污染群の腸管内容はもちろんであるが，腹水中からも大腸菌が full growth の状態とも いらことが出来る程の極めて大量が検出された。大腸菌単独污染群では無菌群と異なり， 血中にエンドトキシンが明らかに出現する事実が，抗エンドトキシン・ウサギ血清を用 いた microtitorによる感作血球凝集阻止反応によって確認された。

\section{緒}

イレウスや腹膜炎さらには急性閉塞性化膿性胆管炎 患者に適切な外科的治療と充分な水分電解質の補給, 大量の抗生物質投与なとを行ない，安心していると患 者が突然シッョック状態に陷り, 死亡することがある.

教室では，長年この死因を中心とする病態生理につ いて，主として腸管内細菌を中心に臨床的に研究する とともに, 有菌の普通動物や細菌の完全な欠除状態に ある無菌動物を用いて実験的にる研究し, 腸内細菌之 くにクラム陰性桿菌の Endotoxinの血中への出現, 増 量がこれら患者のショックの重要な一因子であること
を立証、報告し、外科臨床におけるェンドトキシン ショックの発来性について提唱してきた。

ところで上述血中ェンドトキシンの立証には主とし て実験的に感作血球疑集阻止反応を使用したるのであ るが，近年血中ェンドトキシン検出法として，カブト ガニの血球成分を利用した Limulus Lysate Coagulation Test が1970年 Levin ら”により研究報告されて 以来，本法は俄に臨床的に応用されるよらになった。 そこで今回著者は，本法を用いて教室に入院手術し た腹膜炎を中心とする消化器疾患患者のエントトキシ ン血症（以下ET 血症）について報告するとともに䧗 
膜炎の死因について主として無菌動物を用いて実験的 に研究したので，その成績を報告する．

\section{エンドトキシン血症に関する臨床的研究}

\section{I. 研究材料}

1）昭和 49 年 1 月より昭和55年 5 月迄の約 6 年間に 教室に入院手術された消化器疾患患者の5ち細菌感染 を有するか，あるいはその病態に細菌がーつの重要な 役割を果していると思われる158例の患者の血液につ いて Limulus Testを行なった。

2) Limulus Lysate

（1）国立福岡中央病院隅田幸男博士の好意により提 供された九州産カブトガニ（Techplus Tridetatus）を 用いて Rinhold-Fine ${ }^{2}$ の方法に凖じて作成した Lysate を使用した。

（2）日本産カプトガニより作製，市販されている Pregel ${ }^{\circledR}$ （帝国臓器 K.K）的使用した。

II. 研究方法

1）血液前処置法

(1)クロロホルム法"

ヘパリン $(1000$ 単 $/ \mathrm{ml}) 0.75 \mathrm{ml}$ を含む注射器に無菌 的に $10 \mathrm{ml}$ を穿刺採血し，これを2,000r.p.m. 15分間遠

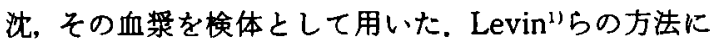
準じてこの血浆の $1 \mathrm{ml}$ に対してクロロホルム $0.25 \mathrm{ml}$ を加えポーテックスミキサーで60分間強く擋伴した 後, $1,100 \mathrm{~g}, 12$ 分間遠沈後中間層を小試験管に採取, こ れを城菌生理食塩水で倍数希釈し，その各々 $0.1 \mathrm{ml}$ 小試験管に採りこれに等量の Lysate を加え， $37^{\circ} \mathrm{C} 1$ 時間佰温槽に静置啳桓温槽上り取り出し 5 分間室温に 静置し判定した. ゲル化の不明瞭なものはさらに 4 時 間後，24時間後再度判定した。

（2）希釈加熱法 ${ }^{31}$

被挨血浆を減菌生理食塩水で希釈し $100^{\circ} \mathrm{C} 10$ 分湯煎 加熱後, この検体を3,000r.p.m. 5 分間遠沈, その上清 を小試跧管に採取し減菌生理食塩水にて倍数希积，そ の各々を $0.1 \mathrm{ml}$ 採取しここに等量の Lysateを加え て判定した。

2) 判定方法

試験管を静かに45度－90度に傾斜しゲル化の有無を 判定した。

（サ）強固なゲルを形成し傾斜しても水平面が崩れ ない状態

（+）ゲルを形成しているが傾斜すると一塊となっ て動き水平面がやや崩れた状態

（土）粗い顆粒状のゲルを形成し明らかに粘度の增
大がみられる状態

（一）白濁のみか又は全然変化のない状態

(\#)〜（士）迄の反応を陽性とし，陽性を示した最大 希积倍数をむって end point とした。

実験器具はすべて $180^{\circ} \mathrm{C} 2$ 時間乾熱隇菌して pyrogen free とし，測定時常き隇菌生理食塩水を対照

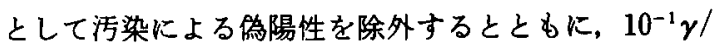
$\mathrm{ml}$ から $10^{-4} \gamma / \mathrm{ml} の \mathrm{E}$. coli $0-26$ エンドトキシン (Difco)溶液を対照として，使用する Lysate の感度を 測定し, $10^{-3} \gamma / \mathrm{ml}$ 迄検出し得る Lysate のみを使用し た.

\section{臨床的研究成积}

I. 消化器疾患手術患者における ET 血症を中心と した細菌学的研究成績

1）消化器疾患手術患者の血液 Limulus Test の成 樍.

最近 6 年間に教室に入院手術された消化器疾患患者 のうち細菌感染を伴ったもの，あるいはまたその病態 に細菌が重要な役割を果していると思われる158例の 血液 Limulus Test の成績は，表 1 に示すように36例 (22.8\%) が陽性を示した。

これをさらに疾患別にみると，腹膜炎63例では，胃・ 十二指腸穿孔15例中 2 例 (13.3\%)，小腸穿孔 5 例中 2 例 $(40 \%)$ ，虫垂炎穿孔12例中 1 例 $(8.3 \%)$ ，大腸穿孔 8 例中 7 例 (87.5\%)，消化管縫合不全 8 例中 2 例 (25\%)，胆道系穿孔15例中 8 例 $(53.3 \%)$ で，腹膜炎 全体では63例中22例 (34.9\%) が陽性を示した。

表 1 消化器疾患手術患者の血洨リムルス・テス 卜成縝

\begin{tabular}{|c|c|c|c|}
\hline \multirow{2}{*}{\multicolumn{2}{|c|}{ 疾患 }} & \multirow{2}{*}{ 例数 } & \multirow{2}{*}{ 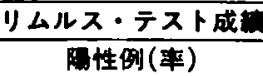 } \\
\hline & & & \\
\hline \multirow{3}{*}{ 樶 } & 田·十二指鸠案孔 & 15 & $2(13.3 \%)$ \\
\hline & 小腰 孔 & 5 & $2(40.0 \%)$ \\
\hline & 虫垂 第 孔 & 12 & $1(8.3 \%)$ \\
\hline \multirow[t]{2}{*}{ 腆 } & 大酤 第 孔 & 8 & $7(87.5 \%)$ \\
\hline & 消化管䜊合不全 & 8 & $2(25.0 \%)$ \\
\hline \multirow[t]{2}{*}{ 类 } & 䏣道系军孔 & 15 & $8(53.3 \%)$ \\
\hline & 小 計 & 63 & $222^{\circ}(34.9 \%)$ \\
\hline \multirow{5}{*}{ 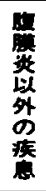 } & $1<$ & 50 & $10(20.0 \%)$ \\
\hline & 化脿性䏣管炎 & 26 & $2(7.7 \%)$ \\
\hline & 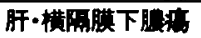 & 11 & $1(9.0 \%)$ \\
\hline & * $\quad \sigma$ & 8 & $1(12.5 \%)$ \\
\hline & 小 & 95 & $14^{*}(14.7 \%)$ \\
\hline & 合 & 158 & $36(22.8 \%)$ \\
\hline
\end{tabular}

$* P<0.01$ 
腹膜炎以外の费患では、イレウス50例中 10 例 (20\%)，

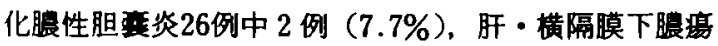
11 例中 1 例 $(9.0 \%)$ ，乙の他 8 例中 1 例 (12.5\%) で， 腹膜炎以外の疾患全体では95例中14例（14.7\%）が陽 性を示した。

すなわち ET 血症の出現頻度は，腹膜炎では $34.9 \%$ で，腹膜炎以外の疾患の $14.7 \%$ に比べて，明らかに高 率 $(\mathrm{p}<0.01) て ゙ ，$ 腹膜炎のらちでもとくに大腸穿孔に 基因する凟便性腹膜炎と，胆道系穿孔に基因する胆计 性腹膜炎が，それぞれ87.5\%，53.3\%で最も高い値を 示した。

2）消化器患手術患者の血液 Limulus Test 之細 菌検索成樍

上述 Limulus Test を行なった消化器疾患手術患者 158例中 culture bottle 法で血液細菌培盖を行なった ものは51例で, Limulus Test と血液細菌培羡の成積を みると, Limulus Test 陽性36例のうち18例が血液細菌 培義が行なわれ，3 例(16.7\%)が細菌陽性で，E.coli， Citrobacta freundi, Eubacterium 各 1 例が検出され,

これらはすべて腹膜炎であった。

また Limulus Test 陰性122例のうちでは，33例に血 液培荃が行われ，8 例(24.3\%)が細菌陽性で Klebsiella 2 例, E. coli, Proteus vulgaris, Eubacterium 各 1 例の他，グラム陽性菌 3 例が検出された（表 2 ）。

すなわち，血液 Limulus Test と血中細菌検索成績 との間には，明らかな相関関俰は認められなかった。

3）消化器疾患手術患者の血液 Limulus Test の成 績之臨床症状

血液 Limulus Test を行なった消化器䂏患手術患者 の白血球数, 発熱, ショック症状などの臨床㱏状と血

表 2 消化器疾患手術患者の血流リムルス・テス 卜と細菌検耊成繶

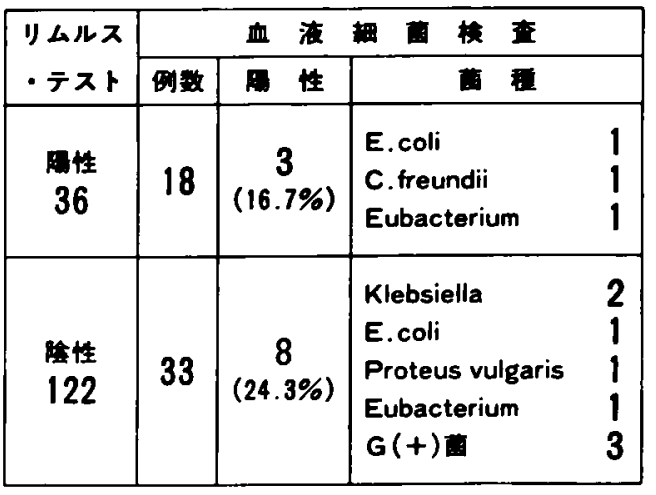

液 Limulus Test の成結との関保をみると Limulus Test 陽性を示した 36 例では，10,000以上の白血球增多 を示したものは18例(50\%)で， Limulus Test 陰性122 例中49例 (40.2\%) と比べて。この両者間にはそれは ど䫒著な差異はみられなかったが，体温38'C以上の発 熱をきたしたるのは，前者では12例(33.3\%)，後者で は20例 (16.4\%)で，発熱は Limulus Test 陽性例では 陰性例に比へて明らかに高い.値を示した（p<0.05）.

また血圧が80 mmHg 以下でショック症状を呈した ののは，前者では12例(33.3\%)，後者では10例(8.2\%) で,ショック症状を呈したすのは Limulus Test陽性 例では陰性例に比べて明らかに高い值を示した（p< 0.01).

すなわち, Limulus Test 陽性例では陰性例に比ぺて 白血球增多の出現率は顕著な美異はみとめられなかっ たが，発熱とショック病状の発現率は明らかに高い值 を示した（表 3 ).

4）消化器疾患手術患者の血液 Limulus Test の成 樍と転帰に関する二，三の検討

消化器疾患手術患者158例中血液 Limulus Test 陽性を示した36例のうち14例が死亡し，死亡率は 38.9\%であったが，陰性を示した122例では20例が死亡 し，死亡率は16.4\%で，Limulus Test 陽性例では陰珄 例に比べて明らかに高い死亡率を示した（p<0.05）。

さらに腹膜炎と腹膜资以外の疾患についてそれぞれ 比較してみると，腹膜炎63例中 Limulus Test が陽性 を示した22例では11例が死亡し，死亡率は50\%であっ たのに対し，陰性を示した41例では 9 例が死亡し，死 亡率は21.9\%で, Limulus Test が陽性を示したるのは 陰性例に比べ明らかに高い死亡率を示した（pく $0.05)$.

表 3 消化器疾患手術患者の血泎リムルス・テス トの成儥と臨床应状

\begin{tabular}{|c|c|c|c|c|}
\hline $\begin{array}{l}\text { リムルス } \\
\text { ・テスト }\end{array}$ & 㣮 & $\begin{array}{c}\text { 白球渞多 } \\
(10,000 \text { 上 })\end{array}$ & $\begin{array}{cc}\text { 武 } \\
\left(38.0^{\circ} \mathrm{C} \text { 以上) }\right.\end{array}$ & $\begin{array}{c}\text { ショック } \\
\text { (ڤE80以下) }\end{array}$ \\
\hline 性 & 36 & $\begin{array}{c}18 \\
(50 \%)\end{array}$ & $\begin{array}{c}12^{n 1} \\
(33.3 \%)\end{array}$ & $\begin{array}{c}12^{n 1} \\
(33.3 \%)\end{array}$ \\
\hline 性 & 122 & $\begin{array}{c}49 \\
(40.2 \%)\end{array}$ & $\begin{array}{c}20^{\circ 1} \\
(16.4 \%)\end{array}$ & $\begin{array}{c}10^{\prime \prime} \\
(8.2 \%)\end{array}$ \\
\hline
\end{tabular}

* $P<0.05$, $2 P<0.01$ 
表 4 消化器疾患手術患者の血液りムルス・テス

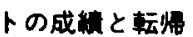

\begin{tabular}{|c|c|c|c|c|}
\hline \multirow{2}{*}{ 的 数 } & \multicolumn{2}{|c|}{ 䒄 性 } & \multicolumn{2}{|c|}{ 隆 性 } \\
\hline & 例数 & 死亡数 & 例数 & 死亡数 \\
\hline $\begin{array}{l}1.2 \\
63\end{array}$ & 22 & $\underset{(50 \%)}{11 * 1}$ & 41 & $\begin{array}{r}9 * 1 \\
(21.9 \%)\end{array}$ \\
\hline 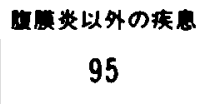 & 14 & $\begin{array}{c}3 \\
(21.4 \%)\end{array}$ & 81 & $\begin{array}{c}11 \\
(13.6 \%)\end{array}$ \\
\hline $\begin{array}{l}\text { 合 } \\
158\end{array}$ & 36 & $\begin{array}{c}14^{* 2} \\
(38.9 \%)\end{array}$ & 122 & $\begin{array}{r}20 \% 2 \\
(16.4 \%)\end{array}$ \\
\hline
\end{tabular}

なお腹膜炎で血液 Limulus Test が陽性を示して死 亡した上述11例の腹腔内膿汁からは，E． coli 8 例, Proteus mirabilis 4 例, Pseudomonas 3 例のほかに Citrobacta freundi, Eubacterium, Seratia, K. pneumoniae $\mathrm{Cl}$. perfringens 各 1 例とほとんどの例か らE. coli を中心とするクラム陰性桿菌が検出された。

腹膜炎以外の疾患95例では，Limulus Test 陽性を示 した14例では 3 例が死亡し，死亡率は21.4\%であった のに対し，Limulus Test 陰性を示した81例では11例が 死亡，死亡率は $13.6 \%$ ，陽性を示したものは陰性を 示したものに比べて高い死亡率を示したが，統計学的 には有意の差は認められなかった（表 4)。なお述 Limulus Test 陽性を示した36例について血装希釈倍 事に上る本反応をみると，22例は被検血浆原湤ですで に陽性を示したが，14例では陰性を示した。この14例 では血を希积していくに従って陽性を示し、いわゆ る阻止帯を呈したか，これら症例のらち7例までが胆 计性膜腹炎であった。

さらに本反応の希釈倍率の end point 上転帰之の関 俰をみると、512倍，256倍という高い值を示している にもかかわらず生存している症例すあり，逆に 1 ～ 8 倍という低い値を示しているにもかかわらず死亡して いる症例むあり，また本反応強弱と転㷌の関係をみて む， $(H) \sim(+)$ とい5強い反応を示してえるにもかか わらず生存している症例むあり，逆に(土)という弱い 反応を示しているにもかかわらず死亡している症例む あり，本反応の希釈倍率の end point や反応の強弱之 転帰との間には明らかな関係はみられなかった。

5) 症例提示
64歳男子（S状結腸穿孔性腹膜炎）

20歳のとき急性堅炎，30歳のとき肺結核の既往があ るほか家族歴にも特記すべきことはない。

昭和53年 5 月 11 日正午頃突然下腹部に激痛をきたし 某医受診，その後疼痛は次第に増強してショック状態 に陥り，翌12日正午，急性腹症の診断で当外科に紹介 され入院した。

入院時患者は顔面倉白, 冷汗を呈し, 舌は乾燥, 厚 い黄色の苔を衣し，脈拍頻数硙弱，意識混濁，血圧は 測定し得ない程のショック状態を呈していた。腹部は 平坦，腹壁㗨張高度で全般に著しい压痛を呈した。

体温は35. $7^{\circ} \mathrm{C}$, 赤血球数 $460 \times 10^{4}$, 白血球数 4,200 , $\mathrm{Ht}$ 值 $44 \%$, BUN $30 \mathrm{mg} / \mathrm{dl}, \mathrm{Na} 143 \mathrm{mEq} / \mathrm{L}, \mathrm{K} .3 .5$ $\mathrm{mEq} / \mathrm{L}, \mathrm{Cl} 122 \mathrm{mEq} / \mathrm{L}$, 血液 Limulus Test は(\#)強陽 性, 血液細菌培善陰性.

図 1 は本患者の術前, 術後の臨床経過にしたがって 血圧，眽拍数，体温、呼吸数などを示したものである が，患者に輸血，輸液，抗生物質，副腎皮質ホルモン， 昇圧剤の投与などを強力に行なってショック状態の改 善をはかりながら急性汎発性腹膜资の診断で開腹する と，腹腔内は䔬便を混じた大量の膿汁に满たされ，こ れを吸引除去すると， S 状結腸に多数の憩室を認め， その一つが炎症を起して穿孔これを切除し，全身状態 はなはだ不良の為 Hartmann 手術を行なった。術後第 6 病日までドパミン，ノルアドレナリンなどの昇圧剤 を使用しないと血圧を維持し得ないはどの高度の循環 障害に加えて ARDSを併発し、レスピレーターの使用 で酸素分圧をかろらじて保つほどの呼吸障害を呈し たそ間 $\boldsymbol{\gamma}$-クロブリン，トラシロールの投与，血小 板輸血などを行ない, 第 7 病日に至ってようやく血圧, 呼吸が安定した。本症例では腹腔内膿汁から108とい きわめて大量の E. coli が娭出されたが, 血液細菌培盖 は陰性を呈した. Limulus Testは術後第 2 病日まで (十)の陽性を示したが, 第 4 病日以降は陰性となり, かららじて一命を救助することができた。

\section{腹膜炎に関する実験的研究}

\section{I. 実験材料}

1) 無菌マウス

使用した無菌マウスはビニールフインレーターを用 いて飼育した JCL : ICR 采無菌マゥスで、生後 8 週体 重30－35g のものを雌雄の別なく使用した。

2）使用培地

E. coli の検出には DHL 寒天培地（栄研）を使用し た。 


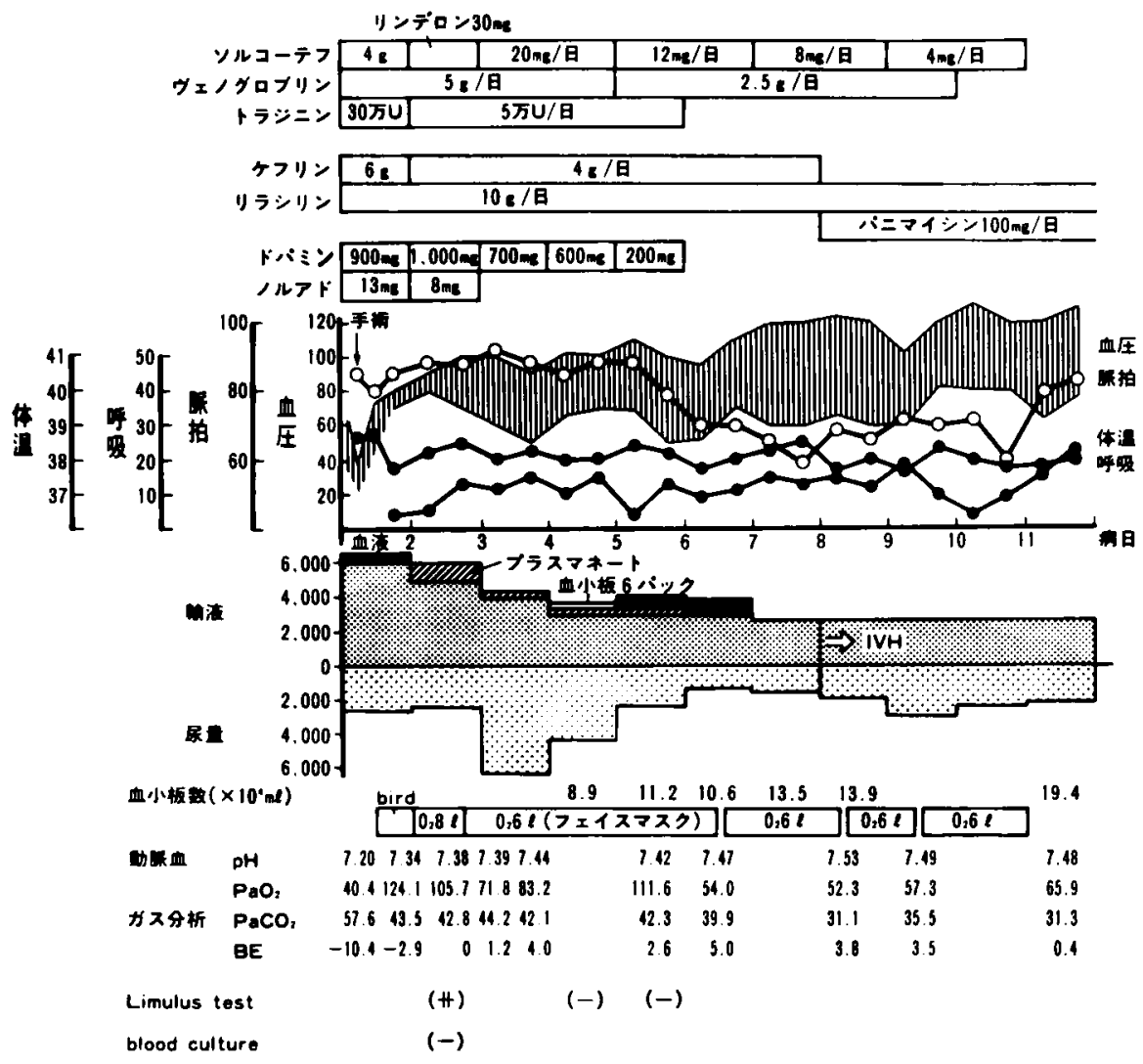

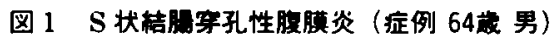

\section{II. 実験方法}

\section{1) 腹膜炎の作製法}

ICR 系無菌マウスを2 群に分ち，1 群は対照無処置 群とし, 他の 1 群はヒト䔬便由来の E. coli-026(Difco) 菌液 $0.1 \mathrm{ml}$ (菌数約 $10^{9}$ 個) を金属カテーテルで経口的 に接取，24時間定着せしめた単独污染群とし，この両 群をビニールフイソレーターの中で回腸末端より2 $\mathrm{cm}$ 上部の回腸を腸管膜血管を損傷しないよ5に充分 に注意して切断，穿孔性腹膜炎を惹起させた。

\section{2）実験動物の生存時間}

上述のよ5に腹膜炎を作製後ビニールフインレー タ一内に放置し両群の生存時間をそれぞれ観察した。

3）腸管内および腹水中の細菌数

腹膜炎作製後12時間と死亡時腹腔内に隇菌生理食塩 水を $2.0 \mathrm{ml}$ を注入してよく洗淮, 洗淮液を採取,さらに 十二指腸直下部の上部小腸管 $1.0 \mathrm{~cm}$ 採取, 検量後ホモ シナイズし10倍希积系列を作製, 腹水 $2.0 \mathrm{ml}$, 腸管内容 $1.0 \mathrm{~g}$ 当りの細菌数を算定した。

4) 血中 Endotoxin の検索法
抗エンドトキシン・ウサギ血清を作製し，感作血球 凝集阻止反応により，血中の Endotoxinを検索した。

すなわち Microtitorを用いて, 被検材料 $0.025 \mathrm{ml} に$ 抗エンドトキシン・ウサギ血清 $0.025 \mathrm{ml}$ を加えて, $37^{\circ} \mathrm{C}$ 4 時間 incubate し, 一夜水室に保存した後, $\mathrm{pH} 7.2$ リ ン酸緩衝液 (P.B.S.)で 2 倍希釈し， $2 \%$ エンドキシ ン感作血球をそれぞれ $0.025 \mathrm{ml}$ ずつ加えて $37^{\circ} \mathrm{C} 2$ 時間 incubate した後，その凝集の有無を判定した。

（1）抗エンドトキシン・ウサギ血清の作製法

E. coli 0-26Endotoxin (Difco) を $\mathrm{lmg} / \mathrm{ml}$ となるよ 5 に堿菌生理食塩水に浮遊させ，その $1 \mathrm{ml}$ を Freund' s complete adjuvant に瑟濁，3日毎に 3 回，体重 1.5 $\mathrm{kg}$ のウサギの腎能に这射し，その後 $10 \gamma / \mathrm{ml}$ 含有減菌 E. coli 0-26Endotoxin 浮游生理食塩水を $\mathrm{lml}$ ずつ週 2 回， 2 週間合計 4 回にわたり耳静脈より注射し，最 終感作後10日目総頚動脈よひ全採血して実䄼に供し た.

（2）感作血球の作製法

$2 \mathrm{mg} / \mathrm{ml}$ の割合で E. coli 0.26 Endotoxin を含有す 
るP.B.S.を $100^{\circ} \mathrm{C} 2$ 時間煮沸隇菌後, これに減菌 P.B. S.を加穴て $100 \gamma / \mathrm{ml}$ エンドトキシン含有液とし，これ に無菌七ッシ血球を加えて，2\%七ッシ血球浮游液と し, $37^{\circ} \mathrm{C} 2$ 時間, 振湯培盖器を用いて incubate, その後 P.B.S. をさらに加えて2.000r.p.m. 5 分間で 3 回洗淮 後P.B.S.に再浮游し，2\%エンドトキシン感作血球浮 游液を作製した。

腸管穿孔性腹膜炎における動物の生存時間，腹水お $よ U$ 䐙管内容の細菌学的研究成績と血中 Endotoxin の消長に関する研究成績

\section{I. 腹膜资峌物の生存時間}

無菌群の生存時間は最短158時間，最長170時間，平 均164時間であったのに対し，大腸菌単独污染群では最 短20時間，最長34時間，平均26時間で，大腸菌単独污 染群の生存時間は無菌マウス群のそれに比べ約 $1 / 6$ と い5短縮がみららた（图 2 ).

\section{II. 腸管内容および腹水中の大腸菌数}

無菌群の腹腔内と腸管内容は対照無姏置群と同様に 全く無菌であったが，大腸菌単独污染群では腸管内容 中の大腸菌数は，腸管穿孔前すでに $1.1 \times 10^{8} \sim 5.6 \times$ $10^{8}$ 個と full growth の状態にあり，腸管穿孔後死亡時

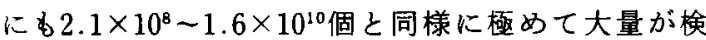

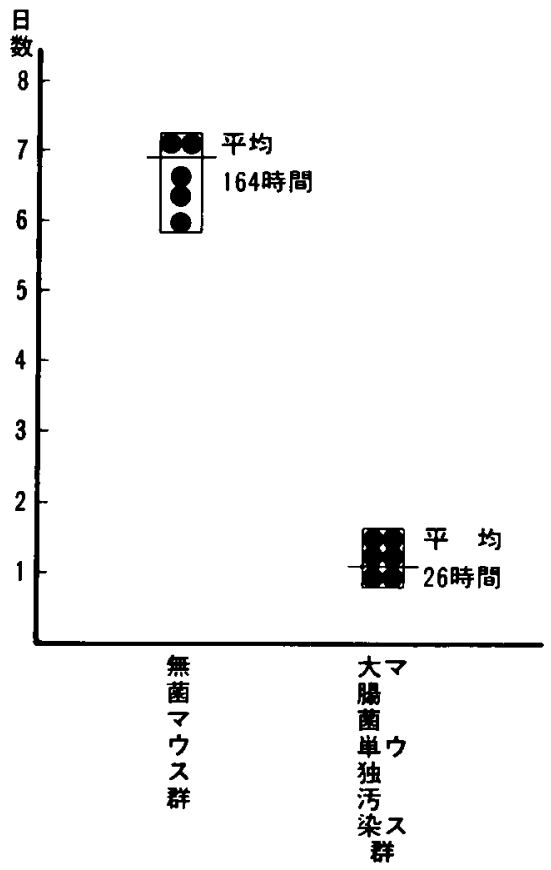

図 2 小腸穿孔性腹膜资大腸菌単独污染マウスの 生存時間
表 5 大腸菌単独污染マウス群の上部小腸管内大 腸菌数

\begin{tabular}{|c|c|}
\hline マウス番号 & 菌 数 \\
\hline No. MG 1 & $1.1 \times 10^{8}$ \\
\hline No. MG 2 & $4.3 \times 10^{10}$ \\
\hline No. MG 3 & $1.6 \times 10^{10}$ \\
\hline No. MG 4 & $5.6 \times 10^{10}$ \\
\hline No. MG 5 & $2.5 \times 10^{10}$ \\
\hline
\end{tabular}

表 6 大腸菌単独污染マウス群の穿孔性腹膜资死 亡時の上部小腸管内大腸菌数

\begin{tabular}{|c|c|}
\hline マウス番号 & 成縤 \\
\hline No. GH 1 & $4.1 \times 10^{8}$ \\
\hline No. GH 2 & $2.1 \times 10^{8}$ \\
\hline No. GH 3 & $1.5 \times 10^{10}$ \\
\hline No. GH 4 & $5.2 \times 10^{8}$ \\
\hline No. GH 5 & $1.6 \times 10^{10}$ \\
\hline
\end{tabular}

表 7 大腸菌単独污染マウス群の穿孔性腹膜炎死 亡時の腹水中大腸菌数

\begin{tabular}{|c|c|}
\hline マウス番号 & 成綪 \\
\hline No. MP 6 & $1.6 \times 10^{10}$ \\
\hline No. MP 7 & $2.1 \times 10^{8}$ \\
\hline No. MP 8 & $4.6 \times 10^{10}$ \\
\hline No. MP 9 & $2.7 \times 10^{10}$ \\
\hline No. MP10 & $8.1 \times 10^{9}$ \\
\hline
\end{tabular}

出されたばかりでなく，腹水中からも $2.1 \times 10^{8}-4.6 \times$ $10^{10}$ 個と大量が検出された（表 5, 6, 7).

III. 血中 Endotoxin $の$ 消長

無菌群と大腸菌単独污染群の血清について Endoto\&inの消長を追求すると，無菌群では死亡時でも 


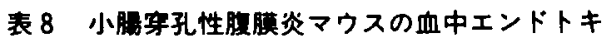
シンの消長

\begin{tabular}{|c|c|c|c|c|c|c|c|c|c|c|c|c|}
\hline 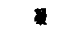 & a & 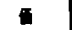 & $\times 6$ & $\times 12$ & $\times 24$ & $\times 4$ & $\times 96$ & $\times 192$ & $\times 384$ & $x 78$ & $\times 1596$ & $\times 5012$ \\
\hline N & & n & 世11 & 卅 & H & 輀 & H & H & \# & $H$ & + & - \\
\hline \multirow{3}{*}{ 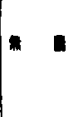 } & \multirow{2}{*}{ t } & No.GPI & 曲 & 㘫 & H & H & \# & $H$ & $H$ & + & + & - \\
\hline & & No.GP2 & 卅 & 些 & 曲 & H & $H$ & $H$ & + & + & + & - \\
\hline & 6 & No.GPJ & 曲 & 曲 & 曲 & 卅 & $H$ & $H$ & $H$ & + & + & - \\
\hline マウスタ & & No.GPS & 州 & H & 曲 & 鈔 & \# & $H$ & $H$ & + & + & - \\
\hline \multirow{3}{*}{ 大 $\mathbf{0}$} & \multirow{3}{*}{12} & No.MPI & 典 & 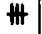 & H & $H$ & + & + & - & - & - & - \\
\hline & & No.MP3 & \# & H & $H$ & + & + & - & - & - & - & - \\
\hline & & No.MPs & \# & 卅 & H & + & + & - & - & - & - & - \\
\hline 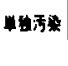 & & No MPs & \# & H & \# & + & + & - & - & - & - & - \\
\hline \multirow[t]{2}{*}{ マクス霖 } & $t$ & No.MP7 & \# & \# & $H$ & + & + & - & - & - & - & - \\
\hline & & No MPg & $H$ & H & $H$ & + & - & - & - & - & - & - \\
\hline
\end{tabular}

対照とほぼ同様に1，536倍であったが，大腸菌単独污染 群では腸管穿孔後12時間，死亡時ともに48－192倍で， いずれす著しく低下した（表 8$)$.

すなわち大腸菌単独活染群では無菌群と異なり腸管 が穿孔，腹膜资を惹起すると血中に Endotoxin が明ら かに出現する事実が確認された。

近年抗生物質の著しい研究開発にともなって細菌感 染症は大きくその様相を異にし，従来しばしばみられ たグム陽性菌による感染症は减少の一途をたど， 既存の抗生物質に対して強い抵抗を示すブラム陰性 菌、とくに桿菌による重傷感染症が激增していること はすでに周知の事実であるが，Weilら゙がグラム陽性 菌の敗血症性ショックでは43\%死亡したのに対して， クララ陰性菌の敗血症性ショックでは90\%とその大半 が死亡したと報告しているよ5に, 今日外科実地臨床 上本菌による敗血症ないしはET 血症が極めて重大な 問題として注目されている。

私どすの教室では，長年にわたる腸管内細菌を中心 とした一連の臨床的ならびに実験的研究を行なって， イレウス ${ }^{5)-111}$ や腹膜炎 ${ }^{121214}$, さらには重症胆道感染

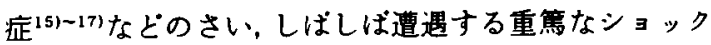
の発来には大腸菌を中心とするグラム陰性桿菌の Endotoxinの血中への出現が 1 つの極めて重要な役割を 果していることを立証報告してきたか，最近 6 年間に 教室に入院, 手術された消化器疾患患者の5ち細菌感 染を有するか、あるいはまたその病態に細菌が一つの 重要な役割を果していると思われる158例の血液 Limulus Testを行なった成績をみると，血中 En- dotoxin が検出されたものは36例 (22.8\%)でこれを 疾患別にみると腹膜炎 63 例では22例( $34.9 \%)$ ，腹膜炎 以外の疾患95例では14例（14.7\%）で，腹膜炎では腹 膜炎以外の疾患に比べて明らかに高率を示し，腹膜炎 のらちでるとくに大腸穿孔による筫便の漏出と, 胆石 症を中心とする胆道疾患の穿孔による洉染された胆汁 の漏出に基因寸る腹膜炎がそれぞれ $85.4 \% ， 53 \%$ と最 も高かった。腹膜炎以外の疾患ではイレウスが50例中 10例 (20\%) で最む高い值を示した。

ところで近年本邦に於いて，消化器疾患に打ける ET 血症の検索成績が多数報告されているか，それら の5ち大部分は腹膜资あるいは胆道感染症に高い陽性 率がるれたと述べている。

水野 ${ }^{18)}$ はT 血症を疑わせしめた62例に血液 Limulus Test 施行し，33例が陽性で，それらの中で 絴合不全に伴5汎発性腹膜炎（14例）および胆道感染 症 (11例) にET 血症が多く認められ，前者は病態が 重篤で死亡率が高かったと述べており，川山年す血液 Limulus Test により121例中85例に臨床的 ET 血症を 証明したか，腹部外科領域では胆道感染例や消化管穿 孔，释合不全など腹膜炎，腹腔内膿瘍例なとに ET 血 症が多くみられ，腹膜炎ではとくに予後が不良である と述べている。

高尾ら ${ }^{201}$ は急性腹症125例に血液 Limulus Test 行ない，45例にET 血症を証明し、これらのらち穿孔 性腹膜炎症例では，外科的治療により Limulus Test が陰性化する例が多いと述べて拈り，土屋ら ${ }^{211} は 228$ 例 の患者について計433回に血中 Endotoxinの検出を試 み，97例に Endotoxin を証明したが，感染症疾患では 胆道感染，腹膜炎が主なものであり，腹膜炎では55例 中19例が陽性でその5ち8例が死亡し，胆道感染症に 比ぺて ET 血症の発生率は低いか，予後は極めて悪い と述べている.

ところで ET 血症と血中細菌との関係をみると, ET 血症18例中血中に細菌の検出されたすのは僅かに3 例 で、しかもこの5ち1例はグラム陽性菌であり，ET血 症を呈しなかった33例では，血中に細菌の検出された ものは 8 例あり、これら8例のうち4 例がグム陰性 菌で, ET 血症上菌血症とは必ずしも一致しなかった。 Levin $5^{22)}$ む281例のグラム陰珄菌敗血症の疑われた 症例について血中 Endotoxin と血中細菌を検討し， ET 血症を呈したものが14\%，菌血症を呈したすのが 18\%，ET 血症を呈したるののなかで菌血症の証明さ れたものは僅かに $7 \%$ \%ずず，ET 血症と菌血症と 
は必ずしも一致しないと述へてているが，ころらの事実 は血中 Endotoxin は血中に出現した細菌に由来する ものではないことを示するのと考えられる。

つぎにET 血㱏を呈したものと星しなかったものの 両群について白血球数，発熱，ショック症状などの臨 床症状を比較すると，10.000以上の白血球数増多を示 するのは両群の間に顕著な差異はみられなかったが， 体温 $38^{\circ} \mathrm{C}$ 以上の発熱をきたしたものは前者では $36.1 \%$ ，後者では $16.4 \%$ ，血王が80 $\mathrm{mmHg}$ 以下で ショック症状を呈したものは前者では33.7\%, 後者て は8.2\%で，ET 血症を呈したものでは呈しなかったも のに比べて発熱とショック症状の発現率は明らかに高 い值を示した。

またこの両群の転㷌を比較してみると，前者では死 亡率が38.9\%であったが，後者では16.4\%で, ET 血症 を呈したものは，呈しないものに比べて死亡率が明ら かに高い値を示した。

さらにこれを腹膜炎と腹膜炎以外の疾患に分けてそ れぞれ比較してみると，腹膜炎ではET 血症を呈した ののは死亡率が50\%であったのに対し，ET 血症を呈 しないものでは21.9\%で，ET 血症を呈したものでは， 呈しないものに比べて明らかに高い死亡を示した。な お ET 血症を呈して死亡した腹膜炎患者の腹腔内膿汁 のほとんどの例から E. coli を中心とするグラム陰性 桿菌が検出された。

腹膜炎以外の疾患では，ET 血症を呈したものの死 亡率は $21.4 \%$ ，呈しなかったものでは13.6\%で, ET 血 症を呈したものでは，呈しなかったものに比べて高い 値を示したが，梳計学的にはこの両群の間には腹膜炎 患者におけるほどの顕著な差はみられなかった。

なお Limulus Testを行ならにあたっては前処置と して血中阻害物質の除去操作としてクロロホルム法” あるいは希釈加熱法引を行なっているが, ET 血症を呈 した36例について血学希釈倍率による Limulus Test の反応をみると，25例は被検血浆原夜で陽性を示した が，11例では陰性を示し，この11例では血䌽を希釈し ていくに従って陽性を示し，いわゆる阻止帯を呈した。

玉熊ら ${ }^{233}$ は in vitroの実験で胆汁中に含まれる主な 抱合胆汁酸である Tauro 並びに Glycochenodeoxy cholic acid が本反応を抑制すると報告し，黄㾞血では 非黄疾血と同じ方法では false negativeになりやすい と述べているが，私の上述阻止帯の認められた 11 例中 7 例までが胆道疾患の穿孔による腹膜炎で, 黄㡺血で あった。
さらにまたこの希釈培率の end point と䎐帰との 関保をみると256-512倍といら高い値を示しているに もかかわらず生存しているもの，逆に1－8倍と低い 值を示してといるにもかかわらず死亡しているものも あり，また本反応の強弱と転帰もとの関係をみても (H) （+）といら強い反応を示しているにもかかから ず生存しているものもあり，逆に(土)といら弱い反応 を示しているにすかかわらず死亡しているものもあ ク, 本反応の血浆希釈培率の end point や反心の強弱 と転帰との間には明らかな関保はみられなかった。

すなわち Limulus Test の陽性頻度は症状ないしは 転㷌と極めて相関したが，本法の血浆希䣋倍率の end point や反応の強弱と転帰との間には一定の関係はみ られず，本法は血中 Endotoxin の定量法としての意義 は認め難かったが，定性反応としての意義は充分ある わのと考点られる。

以上は細菌感染を有するか，あるいはまたその病態 に細菌が一つの重要な役割を果しているものと考光ら れる外科的消化器疾患手術患者に拉ける ET 血症を中 心とした細菌学的研究成績であるがこれらの研究成 績より腹膜炎，とくに大腸穿孔による罴便の漏出と， 胆石症を中心とする胆道系疾患の穿孔による胆汁の漏 出にもとずく腹膜炎に ET 血症を呈するものが多く， これらの症例に沶いては症状子激烈で, 死亡率が著し く高いばかりでなくこれら死亡例の腹腔内膿汁から はいずれる E. coliを中心とするクラム陰性桿菌が検 出された事実は，これら細菌の腹腔内感染と血中 Endotoxin の出現が腹膜炎の病態ないしは死因において 一つの極めて重要な役割をはたしていることを示すむ のと思われた。

そこで無菌動物を用いて実験腹膜炎におけるET 血 症の発来を中心として以下述ぺるような一連の研究を 行なった。

無菌マウスを雌雄の別なく2 群に分ち，1群は対照 無処置群とし，他の 1 群はヒ卜䔬優由来の E. coli 0 -26を単独污染させて24時間後, フインレーターの 中でこの両群に腸管穿孔性腹膜资を惹起させて，この 両群の生存時間を追求するとともに, 穿孔後12時間と 死亡時の腹水および腸管内容中の大腸菌数と血中 En. dotoxinの消長を追求した。

その成績によると，無菌群の生存時間は最短158時 間，最長170時間，平均164時間であったのに対し，大 腸菌単独污染群では最短20時間, 最長 34 時間，平均 26 時間で, 大腸菌単独污染群の生存時間は無菌マウス群 
のそれに比へてて約1/6という短縮が、るられた。

このような両群の著しい生存時間の差異は大腸菌の 污染の有無によるるのと判断せざるをえない．

そこでこれら両群の腹水と腸管内容における細菌検 索を行ならと，無菌群の腹腔内容と腸管内容はまった く無菌であったが，大腸菌単独污染群では腸管内容中 からはもちろんではあるが, 腹水中からも full growth の状態ともいらことが出来るほどの極めて大量の大腸 菌が検出された。

さらにまた，無菌群と大腸菌単独污染群の血液につ いて抗エンドトキシン・ウサギ血清を用いて microtitorにより感作血球凝集阻止反応を行なって血中 Endotoxinの消長を追求すると，大腸菌単独污染群で は無菌群と異なり，腸管が穿孔，腹膜炎を惹起すると 血中に Endotoxin が明らかに出現する事実が確認さ れた。

以上無菌マウスを用いた実験的研究成績は上記の臨 床的研究成績と照合して，E. coli を中心とするクラム 陰性桿菌の腹腔内感染と血中 Endotoxin の出現か，腹 膜炎の病態ないしは死因においても一つの重要な役割 をはたしている事実を明瞭に立証し得たるのといらこ とができよう。

ところでFine 24 (1960)は，イレウス患者における 最初の大きな变化は通常水分および電解質平衡の破綻 でむしすみやかに診断し，これに適切な外科的手術 を加えて水分電解質平衡を修復するならば，イレゥス の病態は速かに改善されるものであるが、このような 患者か腸管穿孔による腹膜炎をおこしていなくても突 然重篤なショック状態に陥ることがあり、このような 場合はグラム陰性の腸内細菌の Endotoxinがショッ クの原因で，このようなショックは嵌頓へルニフを還 納した直後にかなりの患者におきると述ぺている。

この Fine ${ }^{25 / 26)}(1957,58)$ のエンドトキシン説は外 偒性ショックで死亡する場合，その毒素の由来する全 身なしいは局所感染がくても，クラム陰性の腸内細 菌の Endotoxin が門脈を経て侵入し，生体とくに肝の 防衙能力が障害されていると，この Endotoxinが全身 循環に侵入し, ET 血症がおこり,フドレナリン系との 関係のもとにショックを不可逆にするとい5のであっ て, Fine $\mathrm{e}^{26)}$ はさらにつぎのように述へている。

すなわち $\mathrm{p}^{32} て ゙$ 標識した大腸菌を腸管内に投与する と不可逆ショック時にのみ Endotoxinが証明される. またショックの臨界期にある動物に Endotoxinを含 む血液を輸血すると不可逆相に移行する。非吸收性抗
生物質の腸管内投与がショックの進行を防止しらるこ ともエンドトキシン説を支持する。解毒機能は網内系 で行なわれ、ショックより回復直後のウサギはEndotoxinに対し10万倍む敏感で，それたけ解書機能の 低下が寴われるといらことである。

さらにCuevas Fine27らは，ウサギを用いて各種の 細菌性，非細菌性腹膜炎を作製し，血中ならびに腹水 中の細菌とEndotoxinの消長を検討して, 血中に出現 する Endotoxinの主な発生起源は腹劦内に增殖した 細菌ではなく，腸管内に増殖した細菌で，この細菌か ら遊離した Endotoxin が腸管を通して腹腔内に出現 し、さらに腹膜を介して血中に出現すると述へている。

他方 Endotoxin の門脈血中への出現に関しては，す でに内外諸家 ${ }^{28)-32}$ により多数報告されているところ であって，とくに Jacob ${ }^{32}$ は各種疾患により開腹術を 受けた患者の門脈血を手術中採取，細菌学的検索を行 ならと同時に Limulus Test を行ない，細菌は11例中 1 例にE. coliを証明したのみであったが Limulus Test は33例中32例が陽性を示し, Systemic endotoxemia 30例中 4 例に比へてて著しく高頻度であり，種々の 文献的考察を加えてこれら Limulus Test 陽性例仕 false positiveの可能性はなく，すべて portal endotoxemia であると結論し，肝におけるェンドトキシ ンが処理能力をはるかに上まわるほどの Endotoxin が大量であったり，また肝障害などによってこの処理 能力が低下していると，Endotoxinが少量であっても 肝を通り Systemic endotoxemia が生ずると述べてい る.

以上の臨床的ならびに無菌動物を用いた実験的研究 成積より腹膜炎の死因ないしは病態に腸管内細菌とく に大腸菌の Endotoxin の血中への出現が一つの重要 な役割を果していることを立証し得たすのと考える。

$$
\text { むす }
$$

以上外科臨床におけるクラム陰性菌感染症，とくに ET 血症の発来について, 腹膜炎を中心とする臨床的 ならびに実験的研究成樍を基として速べたのである が，これを一括すると次のようである。

I. 1）細菌感染を有するか，あるいはまたその病態 に細菌が一つの重要な役割を果していると思われる外 科的消化器疾患におけるET血症の発現頻度を Limulus Testにより検索すると，腹膜炎では34.9\% で，腹膜炎以外の疾患の $14.7 \%$ に比べて明らかに高率 で，腹膜炎のうちでとくに大腸穿孔による䔬便の漏出 と, 胆石症を中心とする胆道疾患の穿孔による紐菌で 
著しく污染された胆汁の漏出に基因する腹膜炎がそれ ぞれ $87.5 \% ， 53.3 \%$ と最す高い值を示した。

2) Limulus Test と血中細菌検索成耫との間には, 明らかな相関関係は認められなかった。

3）血液 Limulus Test 陽性例では陰性例に比べて 白血球数增多の出現率は顕著な差異は認められなかっ たか，発熱とショック症状の発現率は明らかに高い值 を示した。

4）Limulus Test 陽性例の死亡率は $38.9 \%$ ，陰性 例の $16.4 \%$ 比べて明らかに高い値を示し，とくに腹膜 炎では陽性例が50\%で，陰性例の $21.9 \%$ に比べて著し く高い值を示した。なおこれら腹膜炎死亡例の腹腔内 膿计からはいずれるE. coliを中心とするダラム陰性 桿菌が柆出された。

5）血夜 Limulus Test 陽性例における本反応の血 浆希积倍率と end point 叉反応の強弱と転㷌との間に は明らかな関保はみられなかった。

II. ICR 系無菌マウスを用いた実験に括いて腸管穿 孔により腹膜炎が惹起されると。

1）無菌群の生存時間は最短158時間，最長 170 時間, 平均164時間であったのに対し，大腸菌単独污染群では 最短20時間, 最長34時間, 平均26時間で, 大腸菌単独 污染群の生存時間は無菌マウス群のそれに比べ約 $1 / 6$ といら短緶がみられた。

2）無菌群の腹腔内と腸管内容は全く無菌であった が, 大腸菌単独污染群の腸管内容はむちろんであるが, 腹水中からも大腸菌が full growth の状態ともいらこ とが出来るほどの極めて大量が検出された。

3）大腸菌単独污染群では無菌群と異なり, 血中に Endotoxinが明らかに出現する事実が，抗エンドトキ シン・ウサギ血清を用いた microtitorによる感作血球 凝集阻止反応によって確認された。

稿を終えるにあたり，御指導，御校閲を賜った恩師代田明 郎教授と恩田昌彦助教授に深謝致します。

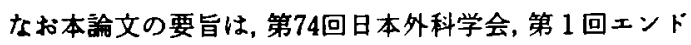
トキシン臨床研究会においてて発表した。

\section{文 嗝}

1) Levin, J., Tomasulo, P.A. and Oser, R.S. : Detection of endotoxin in human blood and demonstration of an inhibitor. J. Lab. Clin. Med., 75 : 903-911, 1970.

2) Reinhold, R.B. and Fine. J.: A technique for quantitative measurement of endotoxin in human plasma. P.S.E.B.M., 137 : 334-340, 1971.

3) Cooperstock, M.S., Tucker, R.K. and Baublis, J.
V.: Possible pathogenikrole of endotoxin in Reyers symdrom. Lancet, 1 : 1272-1274, 1975.

4) Weil, M.H. and Shubin, H.: Diagnosis and treatment of shock. Williams \& Wilkins, Baltimore, 1967.

5）代田明郎，横田秀雄，恩田昌彦法か：イレゥスの死 因を中心とする病態生理に阅する研究一時に無菌 動物を使用して一。最新医学, 24（6）: $1314-1323,1969$.

6）代田明郎，横田秀雄，恩田昌彦はか：無菌動物を使 用したイレウスの研究, 臨床外科, 25： 1583-1588, 1970.

7）代田明郎, 大川共一, 恩田昌彦はか：外科臨床に於 けるェンドトキシンショックの発来性について 一とくにイレウスを中心としてー,外科治療, 26 ： $10-13,1972$.

8）代田明郎, 足立憲治, 宮下正婎仿：外科臨床に於 けるエンドトキシンショックの発来性とその対 策, 日外会誌, 73：1160-1163，1971.

9）代田明郎，三樹 勝，大川共一ほか：イレウスの lathal agent：とくに細菌性因子について, 最新医 学, $27: 1172-1183,1972$.

10）代田明郎：イレゥスショックとエンドトキシン, 日外会誌, $77: 463-469,1976$.

11) Shirota, A., Yokota, H., Hattori, H., et al.: Experimental studies on acute strangulated intestinal obstruction in germfree animals. Inter. Surg., 53: 223-229, 1970.

12）恩田昌彦, 天野汎, 青木博美はか：腹膜炎ショッ クに関する臨床的並びに実験的研究，日外会誌， $75: 1083-1084,1974$.

13）代田明郎，三樹 勝，大川共一活か：腹膜炎手術死 亡例の検討とその対策， 日本医事新報，2621：8 $-13,1974$.

14）代田明郎, 三樹 勝, 大川共一ほか: 急性腹膜炎む エンドトキンンショック，腹膜炎ショックに対す るわれわれの考え方と対策. 外科. $35 ： 368-377$. 1973.

15）代田明郎, 森山雄吉, 足立囊治俰か：エンドトキシ ン血症の発来についててーとくに急性閉塞性化朖性 胆管炎に拈ける胆管由来の細菌性因子之腸管由来 の経門脈的細菌性因子に関する研究成綪を中心と して一，最新医学，35：485-496，1980。

16）代田明郎, 三樹 勝, 吉岡正智ほか：急性(閉塞性 化媳性）胆管炎とエンドトキンン, 胆と䑏， 3 ： 715-724, 1982.

17）代田明郎，山下精彦，足立憲治ほか：腸管由来の程 門脈的細菌性因子一時に内因性エンドトキンン血 症の発来機構一, 日本医事新報, $2974: 23-31$, 1980.

18）水野章：感染症とリムラスラスト，名市大医誌， $28: 1139-1163,1977$. 
19）川山照雄：エントトトキシン血症の実倹的・臨床的 研究，札幌医誌，49：602-618，1980.

20）高尾資郎，帆刏睦男，高場利博：Limulus - Test らみた急性腹症の臨床経過一とくに Endotoxin 血症を中心として一、日臨外医会誌，41： 258-269, 1980.

21 1土屋周二, 嶋田紘：外科とエンドトキンン ショック，外科診療，21：137-147，1979.

22) Levin, J., Poore, T.E., Young, N.S, et al.: Gram-negative sepsis: Detection of endotoxemia with the limulus test. Ann. Int. Med., 76: 1 $-7,1972$.

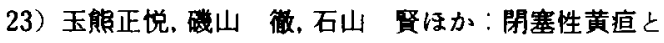
エンドトキンン血症, 外科治療, $38 ： 375-380$, 1978.

24) Fine, J.: The cause of death in acute intestinal obstruction. Surg. Gyne. Obst., $110: 628-630$. 1970.

25. Fine, J.: The bacterial factor in experimental, In shock and circulatory, homeostasis, transaction of fifth conferenced, by H D Green. Tosiah Mayces Jr. Foundation, New York. 1957. P. 37
$-47$.

26) Fine, J.: The role of the intestine in traumatic shock. Am. J. Gastroenterol, 29 : 596-603, 1948.

27) Cuevas, P. and Fine, J.: Role of intraintestinal endotoxin in death from peritonitis. Surg. Gyne. Obst., 134 : 953-957, 1972.

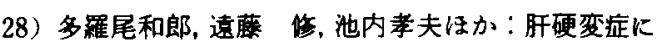
おけるェンドトキンンの研究 (第 I 報), 肝硬変患 者の腹水中のエンドトキンンについて, 日消誌， $73: 1366-1371,1976$.

29）山本祐夫，門奈丈之，藤山進ほか：肝・胆道疾患 に合併したエンドトキシン血症の臨床病理学的検 討, エンドトキンンの基礎と蹊床, 第1回エントト キシン臨床研究会記録, 羊土社：69-75, 1979 。

30）玉熊正悦：Refractory shock 之肝・門脈系の役 割。臨床外科， $24: 13-20 ， 1969$.

31）嶋田 紘：門脈 endotoxin 血症とその意義，医学 のあゆみ、105:20-22, 1978.

32) Jacob, A.J, Goldberg, P.K., Bloom, N., et al.: Endotoxin and bacteria in portal blood. Gas. troenterol., 72 : 1268-1270, 1977. 